\title{
CRIME E IDEOLOGIA: DO TERCEIRO REICH AO ASSASSINATO DE MOISÉS*
}

Verônica Martinelli

Doutora em teoria psicanalítica pelo Programa de Pósgraduação em Teoria Psicanalítica do Instituto de Psicologia da Universidade Federal do Rio de Janeiro; desenvolve atividade de pósdoutoramento no mesmo Programa
RESUMO: Objetiva-se considerar em quais condições o homicídio se torna moralmente aceitável como forma de restauração social. Ademais, trata do funcionamento de certos grupos que legitimam o mal e o crime. Para tanto, recorre-se ao modelo fornecido pelo nazismo. A Alemanha de Hitler estabeleceu novos laços sociais, possi bilitando a legitimação de uma lei de gozo. Considera-se, aqui, o nazismo, sobretudo, como instrumento para uma leitura do M oisés e o monotésmo. 0 texto freudiano aborda a origem do judaísmo, articulando as noções de "estrangeiro" e "assassinato". Freud evidencia, então, que os ideais, o que há de mais nobre em nós, também empuxam ao crime.

Palavras-chave: Psicanálise, ideal, grupo, crime, mal.

ABSTRACT: Crime and ideology: from the Third Reich to the murder of Moses. This article refers to the conditions that make homicide morally acceptable as an instrument for social restoration. It also considers the way certain groups that legitimate evil and crime work. In order to reach these goals, it resorts to the model that $\mathrm{Na}$ zism provides. The Hitler Administration in Germany created new social ties that permitted to legitimate a Law of enjoyment. However, in this article Nazism is essentially a means to draw a particular approach to M oses and M onotheism, by Freud. The Freudian text articulates the notions of "foreigner" and "murder" to deal with the origins of Judaism. Then, Freud evidences that ideals, the noblest objectives we have, favor crime.

Keywords: Psychoanalysis, ideal, group, crime, evil.

*Agradeço a Sérgio Paulo Benevides pela revisão do texto e a Anna Carolina Lo Bianco, pela leitura atenta e observações. 
A questão do mal no século XX adquiriu, nos campos de extermínio nazistas, a face do horror. 0 Terceiro Reich se transformou num marco do declínio moral. No entanto, "a maioria das tentativas de afirmar um tipo de assassinato em massa como pior do que os demais é motivada por preocupações políticas" (NEIMAN, 2003, p.272). Apresentar o Holocausto como o terror único e maior pode servir, por exemplo, para assegurar que qualquer coisa diferente de colocar crianças em câmaras de gás seja relativamente benigna. A dificuldade para graduar atrocidades deriva da falta de um instrumento capaz de medir o sofrimento e a maldade.

Contudo, o Terceiro Reich evidencia aspectos relevantes sobre o mal e o crime, articulando o problema à noção de ideologia e à formação dos grupos. Por isso, será o instrumento para a análise de um dever moralmente pervertido. 0 Holocausto mostra as condições nas quais faz sentido recuperar a questão recusada por Lacan (1963/ 1998, p.780) a respeito de Sade: "Não perguntaremos se é necessário nem suficiente uma sociedade sancionar um direito ao gozo, permitindo a todos valer-se dele, para que a partir daí sua máxima pretexte 0 imperativo da lei moral." Para alcançar nosso intuito, recorreremos ao trabalho de Hannah Arendt. Obviamente, não pretendemos uma discussão exaustiva do tema. Vamos considerar apenas al guns elementos centrais para o debate a que nos propomos.

Segundo Arendt (2000), um dos pré requisitos para que se estabeleça um Estado totalitário é o desenraizamento das massas. A ideologia de tal forma de Estado ganha força nos momentos históricos nos quais tanto as posições quanto as funções das nações e dos sujeitos já não encontram uma ilusão de garantia no Outro. Num cenário como esse, onde havia desestruturação e insegurança, os judeus transformaram-se em catalisadores da intranqüilidade - até "a sociedade desintegrada recristalizar-se ideologicamente em torno de um possível massacre" (ARENDT, 2000, p. 75).

0 crime parece, à primeira vista, essencialmente desagregador. Freud, entretanto, percebeu a capacidade do homicídio para construir, ao seu redor, a fraternidade. Tal idéia foi expressa em Totem e tabu (FREUD, 1913/1996). Afinal, a irmandade originária resultou de um acordo para viabilizar o assassinato do Pai primevo. Partindo desse ponto, a cultura se estabilizou sobre a marca da morte, perpetuada por meio da identificação com o Tirano destituído. Embora a escolha do homicídio como maneira de restauração social não seja surpreendente, podemos nos perguntar em que condições ela se tornou moralmente aceitável.

U ma das principais características do nazismo era o papel do Líder. 0 Führer comandou o Estado proclamando sua responsabilidade pessoal por todos os atos oficiais de cada membro do movimento. 0 totalitarismo indica "um governo no qual o poder é exercido por um só homem" (ARENDT, 2000, p.513). Tal onipo- 
tência se justifica, pois os funcionários não são apenas designados, encarnam o desejo do Chefe - fonte de qualquer ordem.

A função do Líder totalitário, e de sua Lei, é servir de ponto de articulação para o lugar de cada pessoa numa organização orientada por determinada ideologia. Segundo a estrutura apresentada por Freud em "A psicologia de grupo e a análise do ego" (1921/ 1996), tal mecanismo permanece similar ao dos demais grupos. No entanto, em geral, um homem transmite o Mandamento, em vez de se espelhar nele. Além disso, Hitler pretendeu fundar uma nova sociedade apoiada num Imperativo siderante: façam do outro a coisa disponível para qualquer ato livre de pudor e culpa.

Exemplarmente, Eichmann, em seu julgamento em Jerusalém, declarou que seus atos eram crimes apenas do ponto de vista retrospectivo. Fora um inabalável respeitador das leis, pois as ordens assassinas de Hitler "possuíam força de lei no Terceiro Reich" (ARENDT, 2001, p.35). Então, o acusado só cumpria suas obrigações. Tal questão surgiu no interrogatório, quando ele asseverou ter vivido de acordo com o preceito moral kantiano: "Quis dizer que o princípio de minha vontade deve ser sempre tal que possa se transformar no princípio de leis gerais" (ARENDT, 2001, p.153). A fala de Eichmann provoca estranheza porque a filosofia moral de Kant está ligada à faculdade do juízo, eliminando a obediência cega. Todavia o nazismo distorceu o Mandamento ético para: "Aja como se o princípio de suas ações fosse o mesmo do legislador ou da legislação local. [ ...] 0 Imperativo categórico do Terceiro Reich: aja de modo que o Führer, se souber da sua ação, a aprove" (ARENDT, 2001, p.153).

Segundo Kant, todo homem legisla ao agir, e a fonte da Lei é a razão prática. Para Eichmann, tal fonte era o desejo do Führer. Entretanto, o acusado ultrapassou a simples obediência, identificou sua vontade com a de Hitler e fez do Mandamento algo suficientemente absoluto para não comportar exceções. Por isso, ficou constrangido ao confessar o pecado cometido ao condescender com suas obrigações para ajudar um primo meio-judeu, evitando um assassinato. A questão incômoda era perceber como fora não um fanatismo homicida, mas a consciência escrupulosa a responsável pela atitude de Eichmann perante suas tarefas na execução da Solução Final: "Na apologia do crime [...] o Ser supremo é restaurado no Malefício" (LACAN, 1963/ 1998, p. 802). Então, o Terceiro Reich nos mostra que não basta um Imperativo buscado como um dever, para a assunção do sujeito faltoso e capaz de assumir o desejo como se fosse seu.

Assim, como a palavra do Führer tinha a força de Mandamento do mundo, toda regra contrária aos seus pronunciamentos era, por definição, ilegal. Nesse contexto, as ordens geralmente legítimas se tornam inaceitáveis e 0 assassinato transmuta-se em obrigação. Afinal, o horror não implicava uma exceção ao Imperativo vigente; era sua norma: "As categorias do crime são sempre relativas aos 
costumes e às leis existentes. [...] A psicanálise afirma que sua grande determinação é a concepção de responsabilidade recebida pelo sujeito da cultura em que vive" (LACAN, 1950/2003, p.130).

Eichmann, de certo modo, notou como o próprio Mandamento o transformou num facínora. Na maior parte dos países, a voz da consciência dita "não matarás", mesmo que o desejo de alguns seja assassino. Na terra de Hitler, 0 dever era "matarás", embora o homicida pudesse ter anseios mais nobres. Dessa maneira, no Terceiro Reich o mal perdeu a qualidade pela qual muitos o reconhecem: a tentação. Vários nazistas provavelmente se sentiram tentados a renegar o papel de cúmplices da carnificina, porém aprenderam a resistir (ARENDT, 2001).

A Lei total itária estava intrinsecamente articulada a um discurso ideológico. Esse discurso arrumava os fatos sob a forma de um processo absolutamente lógico, que se inicia com uma premissa aceita axiomaticamente, tudo sendo deduzido dela. Age-se, então, "com uma coerência inexistente no terreno da realidade" (ARENDT, 2000, p.523). Graças ao pavor da contradição, tal mecanismo foi irresistível, subjugou a muitos inteiramente. Assim, quem concordasse que 0 direito de viver tinha relação com a raça, concluiria sobre a necessidade de matar os povos ditos inferiores.

O discurso ideológico pressupõe a suficiência de uma idéia para gerar uma compreensão coerente e abrangente do mundo. Logo, contém em si elementos totalitários prontos para se manifestar, para revelar sua estrutura, através de uma ação totalitária. Eichmann se descrevia como um homem capaz de viver para um ideal, sacrificando qualquer coisa em seu favor. Para salientar essa perfeita devoção, disse que mataria o próprio pai se isso Ihe fosse exigido. Em outras palavras, ser idealista não significa deixar de vender a alma ao diabo; significa somente a possibilidade de uma venda absoluta.

Apesar de desafiar as leis positivas, a ideologia nazista não é arbitrária, pois obedece a um suposto princípio natural e histórico que estaria na base de todos os imperativos. ${ }^{1} 0$ regime totalitário alegou recorrer à fonte das leis, de onde receberia sua legitimidade. Assim, o Führer sacrificou interesses vitais e imediatos à execução de um preceito primordial, esperando, dessa forma, engendrar a humanidade ideal como produto derradeiro. Portanto, embora Hitler exercesse 0 poder, permaneceu submetido à lógica do Mandamento a ele identificado.

As leis positivas são mutáveis. Entretanto, se comparadas à transformação constante das ações, indicam estabilidade. Porém, no totalitarismo, o Imperativo dei-

${ }^{1}$ Legitimar a prática legislativa de um governo apoiando-a em um termo pretensamente primeiro, superior e absoluto não é uma peculiaridade do Terceiro Reich. Faz-se o mesmo quando, por exemplo, Deus torna-se a garantia das leis que regulam a sociedade. A diferença se estabelece, então, quando consideramos as características desse princípio legitimador e quais Mandamentos ele justifica. 
xa de ter tal caráter estabilizador, porque se identifica ao próprio movimento. A história, assimilada à natureza, progrediria infinitamente. Então, a idéia de sobrevivência dos mais aptos - apoiada sobre a noção darwinista de evolução - foi usada pelos racistas: o extermínio seria necessário para se atingir um estágio superior.

Como esse movimento de superação seria intrínseco à natureza histórica, não pode ter fim. Se os nazistas conseguissem eliminar tudo o que fosse nocivo e indigno da vida, exterminariam também a lógica do suposto Imperativo primordial: é preciso perpetuar a morte como forma de garantir o poder. Por isso, no Terceiro Reich, o terror - destinado a converter em realidade o ideal da história - toma o lugar das leis positivas. 0 crime não significa simplesmente o meio para oprimir a oposição; representa a essência de um Estado que nega a permanência e se afirma pela transformação.

Em tal regime, os culpados são os entraves ao caminho do progresso, que já emitiu sua sentença a respeito das raças. No julgamento da história, todos os demais atores seriam inocentes: os mortos não agrediram o sistema; os assassinos, por outro lado, só executam o mandado de um tribunal superior.

Assim, o horror implica uma sociedade criada a partir do Mandamento da mudança. Para produzir tal modelo, precisa-se expulsar da realidade justamente o elemento responsável, segundo Freud, por fundá-la: a perda, presente como uma ausência sempre mesma. Esse termo originário alicerça a dimensão histórica e, simultaneamente, está excluído dela. No entanto, o projeto ideal nazista é tão moralmente contundente quanto irrealizável. 0 permanente retorna através de uma negação, pois o próprio movimento deve insistir infindavelmente na busca da comunidade almejada.

Então, no nazismo, o crime se escreve como execução de um Imperativo absoluto cujo fim último não indica o bem comum, nem o interesse individual, mas a fabricação do mundo ideal através da eliminação do sujeito em favor da transformação evolutiva da espécie. Promete-se libertar o dever do desejo fazendo da humanidade a encarnação de uma Lei que, supostamente, não produz falta al guma. Há, dessa forma, a queda de qualquer valor singular, em prol da unificação - da ilusão de milhares serem um. Em vez de diversas pessoas, existe uma espécie.

Portanto, o funcionamento ideológico totalitário tem o efeito de exacerbar a relação especular entre os semelhantes. Como um só corpo social encarnava a Lei promulgada pelo Líder, também a fraternidade se reduzia a um ser composto de milhares de elementos. Hitler via a grandeza de seu projeto em tal exclusão das diferenças. Ele declarou: " [nossos partidários] são uniformes não apenas nas idéias, mas até a expressão facial é quase igual. Vejam seus olhos [...] e ficarão sabendo como cem mil homens podem tornar-se um só" (ARENDT, 2000, p.468). 
Outra característica do movimento era que os nazistas não se detinham perante a prova de realidade. Logo, Hitler conseguiu desprezar a miséria presente e local em favor de uma ilusão paradisíaca a se concretizar num futuro indefinido e distante. Dessa maneira, coloca-se a imagem de um destino pleno sobre a ausência inassimilável e imóvel - o objeto perdido assim como o Pai morto que, segundo Freud, funda a história do sujeito e da cultura: o porvir destitui a origem. A realidade construída por meio de tal mecanismo tem certa similaridade com o delírio. Por isso o assombro e a falta de reconhecimento das demais nações ao olhar para a Alemanha do Terceiro Reich.

0 nazismo cai no abismo entre a realidade, socialmente legitimada, e os ideais que exigem sua transformação. A ideologia, mesmo pervertida, contém ef etivamente um protesto contra a existência atual, pois introduz modelos na cultura e, então, reclama a perfeição em nome deles. Seu método é inscrever, através de uma ficção, um significado novo para a vida, ao desvincular o homem dos significantes produtores das referências antes compartilhadas. 0 séqüito do Führer criou, por exemplo, "regras de linguagem" que não deixavam as pessoas ignorantes quanto a seus atos, porém as impediam de equacioná-los com suas antigas noções de mentira e crime. No lugar do velho mundo, constrói-se outro, escondido sob o presente e capaz de dominá-lo.

Segundo Arendt (2000), o projeto totalitário atua na esfera onde se anuncia: "tudo é possível". Os campos de extermínio foram os laboratórios destinados a demonstrar tal crença. Entretanto, apenas se afastando de uma real idade estabelecida, alguém consegue afirmar algo assim. Esse princípio representa uma das maiores rupturas do Terceiro Reich com o resto da humanidade, porque quase sempre recuamos perante determinadas fronteiras e recebemos com horror 0 gozo monstruoso produzido pela pretensão de subjugar o impossível. Os partidários de Hitler, dispostos a desconhecer qualquer barreira em nome de uma Lei total, só podem despertar o pavor bestial. Nós os vemos como Lázaro ressuscitado.

Para os nazistas se afastarem de seus valores tradicionais, foi preciso destruir os claudicantes laços sociais preexistentes e substituí-los por uma nova organização. 0 grupo reinventado objetivava garantir a verdade da ideologia que supostamente coloca as coisas onde deveriam estar ao exigir a igualdade entre a realidade e os modelos.

Durante a Segunda Guerra M undial, o governo celerado assolou quase a totalidade do povo alemão. Entretanto, nas demais nações a situação foi diversificada: "a lição dos países aos quais se propôs a Solução Final é que ela poderia acontecer na maioria dos lugares, mas não aconteceu em todos" (ARENDT, 2001, p.254). Os partidários de Hitler acreditavam no potencial do anti-semitismo para ser 0 denominador comum capaz de unificar a Europa. Esse foi um erro, pois o terror assumia tantas faces quantas eram as fronteiras do velho continente. Em alguns 
Estados, o Holocausto foi devastador. Na Romênia, por exemplo, até a SS ficou perplexa com os horrores provocados pela população. Os nazistas chegaram a intervir para salvar judeus da barbárie, em favor de um assassinato "civilizado".

Por outro lado, na Dinamarca, não somente os habitantes do local se negaram a participar do programa de extermínio, como os próprios membros da SS deslocados para o país mudaram de posição. Assim, inclusive homens da elite da Gestapo - envolvidos antes na efetivação da Solução Final em nações diferentes - passaram a se recusar a atender as ordens do Führer. Tal exemplo evidencia que o jogo de identificações e ideais constrói e determina o sujeito. Quando se viram numa cultura em que o crime continuava ilegítimo, nazistas recuperaram padrões morais tradicionais - o "não matarás" converteu-se, novamente, numa Lei vigente e numa força oposta ao Imperativo homicida.

Antes de encerrarmos esta rápida apresentação das características do Terceiro Reich, resta-nos fazer algumas considerações sobre o lugar ocupado pelos judeus na sociedade européia. Desde o início, os anti-semitas da Alemanha de Hitler assumiram um discurso supranacional. Visavam a um governo intereuropeu. 0 fato de 0 "povo eleito" constituir, num continente dividido em países, o elemento além das fronteiras indicava a íntima relação entre a sua condição e a ideologia nazista. Unificando as nações através de um projeto racista, pretendiase eliminar os pretensos manipuladores do destino dos Estados, apoderando-se de seus segredos e armas (ARENDT, 2000).

Ainda que os judeus habitassem a Europa há vários séculos, nunca deixaram de representar uma "nação dentro de outra nação" (ARENDT, 2000, p.54). Tratava-se de um grupo sem governo próprio, sem terra, disperso pelos Estados, estranho e estrangeiro em toda parte. Para um movimento com a pretensão de eliminar qualquer diferença em favor de uma raça internacional unificada, o "povo eleito" encarnava 0 alvo, não exclusivo, mas privilegiado: 0 visitante indesejável comum aos países do velho continente. Essa posição das vítimas era tão importante que, em geral, os judeus oficialmente estrangeiros foram os primeiros a serem perseguidos. Ademais, muito freqüentemente, o extermínio era precedido por medidas legais para transformar em apátridas os futuros objetos do sacrifício.

Assim, o Holocausto estava rel acionado à noção de estrangeiro. Porém, curiosamente, a discriminação também foi potencializada pelo crescimento das idéias igualitárias - disseminadas desde a Revolução Francesa. Afinal, a afirmação da igualdade dos homens converteu as diversidades em paradoxo.

Efetivamente, quanto menos se percebiam os judeus como iguais, mais interessantes se tornavam. A cultura burguesa, apaixonada por quem diferia das normas, seduziu-se pelo misterioso, pelo perverso ou mau: "A sociedade, constantemente à espreita do estranho, do exótico, do perigoso, finalmente identifica 0 refinado com 0 monstruoso e se prontifica a admitir monstruosidades" 
(ARENDT, 2000, p.104). A imagem incomum vinculada ao "povo eleito" ajudou a temperar o racismo com o fanatismo capaz de conduzir as massas na direção dos homicídios. Quando promulgaram as leis anti-semitas, foi como se os nazistas expurgassem o mundo de uma depravação, um estigma poderoso pelo qual cidadãos decentes haviam sentido grande atração: "a sociedade [...] estaria agora pronta a purificar-se do mal, reconhecendo abertamente os criminosos para publicamente cometer os crimes" (ARENDT, 2000, p.110). 0 curioso é que encontramos a maior proporção de assassinos nos grupos antes íntimos dos judeus - aqueles que avidamente desejaram o desigual procuraram com pertinácia excluí-lo.

0 nazismo foi um momento particular do século XX que evidenciou as dificuldades e os impasses da apreensão moral. 0 extremo da crueldade e a presença excessiva da morte fazem toda busca de sentido parecer perigosa e inútil. Não existe uma significação pertinente para o horror desmedido. Porém, como apreender, a partir dos conceitos da psicanálise, o funcionamento de determinados grupos que legitimam o mal e o crime?

O Simbólico permite o laço social através de uma Lei ao mesmo tempo interditora e gozosa. No Terceiro Reich, o caráter proibitivo do Imperativo se manteve sob a forma de obediência incondicional ao desejo do Líder humano e pretensamente onipotente, estabelecendo-se, assim, um vínculo orientado pela massiva assimilação da palavra do Chefe. Contudo, o Mandamento da sociedade nazista era governado pelo gozo. Até a interdição guiava o sujeito em sua direção. Quando o significante se estrutura de maneira a exacerbar a incidência do Real, o Imaginário também se torna desmedido; por isso, no Terceiro Reich a identificação dos integrantes do grupo está marcada pela ilusão de uma radical unificação dos sujeitos mutuamente refletidos. Afinal, se a Lei já não cumpre seu papel de contenção, impõe-se ainda mais a necessidade de tamponar o impossível. Tal enodamento do Simbólico com o Imaginário, dominado pelo gozo, assume feições diversas ao longo da história. Todavia, é uma ocorrência tão antiga quanto a vocação do mal e do crime para se transformarem em núcleo de uma ideologia capaz de apoiar um modo de laço social totalizante e, logo, excessivo, que destitui as barreiras construídas pela moral tradicional e pelas leis reconhecidas pela comunidade de Estados.

A crueldade não foi invenção do Terceiro Reich. Horrores como o fogo da Inquisição, o massacre dos armênios e a Primeira Guerra Mundial provam isso. "Até para os historiadores esperançosos, esses acontecimentos bastavam para dissipar qualquer fé ilimitada na humanidade" ( NEIMAN, 2003, p.258). Se olharmos para dois mil anos atrás, veremos um homem açoitado, coroado com espinhos, carregando publicamente o símbolo da sua tortura, e, no fim, pregado numa cruz onde morreu. Tal cena, relembrada nas igrejas, evidencia que os sujei- 
tos há muito se unem ao redor da violência - embora seja diferente idealizar a vítima ou 0 assassino.

No entanto, como foi dito, o nazismo constitui um fenômeno privilegiado para apresentarmos certos aspectos do mal articulado à estrutura de um grupo. 0 Terceiro Reich, obviamente, não nos mostra todos os ângulos da questão. Mas alguns dilemas morais - dos quais falaremos agora - foram especialmente prementes nesse caso.

0 primeiro problema diz respeito à produção do mal como efeito de uma engrenagem na qual as pessoas funcionam como peças de uma máquina mortal. Todas as instituições públicas daAlemanha, pelo menos durante os anos de guerra, estavam envolvidas em ações criminosas. Tal absorção da burocracia por desígnios assassinos justifica a expressão escolhida por Arendt (2001, p.311) para se referir à Solução Final: "massacre administrativo".

Essa estrutura estatal sofria de um curioso amorfismo. As organizações eram incessantemente multiplicadas e o poder transladado sem interrupções. As constantes mudanças atingiam os departamentos, mas também as pessoas. Existia uma infindável transferência de postos e desestimulava-se o contato duradouro entre integrantes do partido: "O isolamento de indivíduos atomizados constitui a base para o domínio totalitário" (ARENDT, 2000, p.457). Dessa forma, a ilusória unificação do movimento se apoiava na impossibilidade de cada sujeito definir seu lugar particular. Como quase ninguém sabia exatamente qual era sua posição, sua missão e o valor de seus atos na máquina, disseminava-se a cumplicidade pela população e, ao mesmo tempo, diluía-se a responsabilidade. Assim, na máquina de homicídios o criminoso transforma homens em cadáveres numerados, porém ele próprio está ausente.

Uma curiosa imagem da destituição do sujeito, produzida no exercício de certa função, é fornecida por Herman Melville (1986) numa pequena novela intitulada Bartleby, o escriturário. 0 livro narra a história de um rapaz contratado por um advogado. A princípio, o novo funcionário cumpria sua tarefa incansavelmente. No entanto, depois de algum tempo, começou a se negar a prestar uma série de serviços, até que, por fim, nada realizava. Ficava, então, longas horas atrás de seu biombo, calado, olhando pelajanela, para a cinzenta parede fronteiriça. Era uma perpétua alma penada, cercada por uma indiferença cadavérica. Nessa insólita situação, o patrão afirmou: "Tivesse sentido qualquer coisa de normalmente humana em Bartleby, que sem dúvida o teria escorraçado do meu escritório. Porém em tais circunstâncias, mais depressa pensaria em atirar pela porta 0 meu busto de Cícero em gesso branco" (MELVILLLE, 1986, p.33).

Com o tempo, percebeu-se que Bartleby vivia no escritório sem jamais sair. Como a situação tornou-se insuportável, o advogado decidiu demiti-lo. 0 rapaz, todavia, sem discutir ou explicar, permanecia atrás do biombo. Perante as 
dificuldades práticas geradas por aquela insólita presença, o patrão retirou-se vendeu a propriedade. 0 funcionário "ali ficou, o imóvel ocupante na sala vazia" (MELVILLE, 1986, p.83). Entretanto, o novo dono, para livrar-se do incômodo e estranho ser, chamou a polícia. Bartleby morreu na cadeia, olhando para uma parede cinzenta.

Alguns meses após a morte, o advogado conseguiu uma vaga informação sobre seu antigo escriturário. Ele teria exercido um cargo subalterno na seção de cartas extraviadas, de onde fora dispensado de repente, por causa de uma reforma administrativa:

"Concebam um homem propenso a uma pálida desesperança: haverá melhor atividade para desesperá-lo do que o contínuo manuseio dessas cartas extraviadas, mortas, e com elas alimentar o fogo? Porque são queimadas todos os anos, às carradas. Por vezes, dentre as folhas dobradas de uma carta, o pálido escriturário retirava um anel - o dedo ao qual estivera destinado estava talvez apodrecendo no túmulo; uma nota de banco retirada remetida com solícita caridade - e aquele a quem se destinava a socorrer já não come, já nem tem mais fome [ ...]. Nas mensagens da vida, tais cartas apressam a morte." (MELVILLE, 1986, p.100)

Bartleby carecia de desejo. 0 rapaz é a peça do escritório. Parado diante da janela, ele perturba por sua perversa ausência permanentemente presente. Vivendo maquinicamente, desconhecia sua missão na sal a fria que, no entanto, abarcava sua vida de forma total. 0 funcionário associado à morte, ao cadavérico, assombra.

No Seminário sobre "A carta roubada", Lacan usa o conto de Edgar Allan Poe. 0 estatuto do "verdadeiro sujeito" da história, a carta, é plural. Todavia, vou pensá-la como o "significante". Boa parte do artigo de Lacan (1956/ 1998) dedica-se a evidenciar a supremacia desse elemento na estrutura da narrativa. Ao longo das cenas, conforme a missiva se desloca, os personagens também ocupam diferentes lugares. Enquanto se movem, vão se modificando suas visões, suas falas... Essa translação enfatiza como nenhum dos atores preexiste a suas posições. Eles estão lá pela força do percurso de uma carta que os comanda: "o deslocamento do significante determina os sujeitos em seus atos, seu destino, suas recusas, suas cegueiras, seu sucesso e sua sorte" (LACAN, 1956/ 1998, p. 34).

Assim, Lacan (1956/ 1998) fala de uma carta cuja função é instaurar, mediante seu circuito, o lugar do sujeito. Melville descreve outra, incapaz de atingir seu destino, porque o caminho foi interrompido. Trata-se de uma mensagem vazia, pervertida e endereçada à morte. Se o significante tem seu percurso impedido, deixa de cumprir sua missão - ao invés de construir o sujeito, o destitui ao demarcar uma posição inapreensível, devastada pelo gozo. 0 Terceiro Reich foi uma monstruosa fábrica de cartas extraviadas. 
O segundo dilema moral evidenciado por meio do Holocausto indica os impasses da idéia de intenção. Como dissemos antes, a engrenagem chefiada por Hitler disseminou a cumplicidade, minimizando a incidência da culpa. Porém, para produzir esse efeito, precisou diluir a força da noção de intenção. Dessa maneira, de acordo com a ideologia nazista, os carrascos representavam apenas objetos a serviço das onipotentes leis naturais. Por isso "em vez de dizer 'Que coisas horríveis eu fiz!', os assassinos podiam dizer 'Que coisas horríveis tive de ver na execução de meus deveres!'" (ARENDT, 2001, p.122). Então, o governo do Führer levou as pessoas a abdicar de suas objeções morais por acreditarem que ações más exigem má vontade. Afinal, os crimes do regime do qual participavam justificavam-se por motivos supostamente aceitáveis. A eficácia de tal método mostra como o sentimento de culpa constitui um critério pouco confiável para avaliar problemas éticos.

Eichmann, por exemplo, declarou até gostar dos judeus. Todavia, enquanto ajudava a efetuar a Solução Final, "só ficava com a consciência pesada quando descumpria suas ordens - embarcar milhões de homens, mulheres e crianças para a morte, com grande aplicação e o mais meticuloso cuidado" (ARENDT, 2001, p.37). Os arautos do horror foram salvos da culpa pela submissão à Lei do gozo. Tal destruição dos preceitos morais e legais instituiu a eficácia maléfica do Holocausto.

A psicanálise nunca se orientou pelo conceito de intenção. Na medida que considera o inconsciente, sua questão aponta para uma direção diferente. Se lembrarmos a tragédia de Édipo - modelar no quadro da teoria freudiana - veremos um homem cujos esforços se exauriram na tentativa de evitar seu destino. Assim, o crime por ele cometido não foi deliberado. A vontade repudiava o oráculo. No entanto, ao contrário de Eichmann, a personagem de Sófocles fica soterrada pela culpa, preço pago pela realização de um desejo inacessível e inaudito. Justamente por indicarmos o mal além do duvidoso jogo das intenções, podemos reafirmar, em outro nível, a exigência de responsabilidade: "Porque a verda de buscada pela psicanálise é a verdade de um sujeito, ela tem que manter a idéia de responsabilidade" (LACAN, 1950/2003, p.131). Afinal, ademais de sermos efeitos da linguagem, nós a produzimos. Os imperativos não são unicamente entidades lógicas, são dizeres constantemente atualizados. Cada sujeito, desejante e dividido, ao afirmar a legislação vigente em sua cultura, demarca sua posição e simultaneamente reinstaura o princípio regulador de certo grupo. Dessa forma, a responsabilidade indica que o poder de um preceito implica sua enunciação.

Segundo Freud, o sentimento de culpa representa um obstáculo à repetição do homicídio - desejado e repudiado - apoiando a produção do sujeito por meio do recalcamento. Todavia, o remorso surgiu, na tragédia de Édipo, a respeito do ato perpetrado contra o Pai. Também Eichmann se arrependeu de cada 
deslize na execução do dever identificado à vontade do Líder. Então, a culpa se torna pouco confiável como critério para julgamentos morais, pois não está vinculada ao Bem, mas à contraditória Lei paterna: "goza!" e "jamais podes gozar!". Por isso, Freud (1930/ 1996) insistia na incidência desmedida, injusta da culpa - capaz de, às vezes, assolar os santos e se desviar dos homicidas. Logo, numa máquina regida pelo Imperativo do gozo, carrascos cumprem a penitência por alguma eventual piedade.

0 último dilema moral que discutiremos, a partir dos eventos ocorridos durante o Terceiro Reich, é a banali dade do mal. Seria cômodo descrever os nazistas como monstros terríveis. Eichmann, entretanto, nos revela algo diferente. Ele não era especialmente sádico ou violento, e sim uma pessoa assustadoramente vulgar. Como dissemos, muitos homens responsáveis pela Solução Final cometeram seus crimes por estarem num ambiente onde foi possível esquecer a distinção entre o certo e o errado - em outras circunstâncias, talvez não entrassem para a história como homicidas: "Se isso é banal e até engraçado, se nem com a maior boa vontade se extrai qualquer profundidade diabólica ou demoníaca de Eichmann, isso está longe de ser lugar-comum" (ARENDT, 2001, p.311). Realmente, nada há de comum em jogar seres humanos nos fornos. 0 nazismo nos mostrou como um evento excepcional conseguiu conduzir ao extremo da maldade: sua banalização.

Esse projeto cultural celerado não teria atingido tamanha proporção no Terceiro Reich, se estivesse restrito a um número limitado de militantes do partido nazista. No entanto, a desvalorização da vida alcançou a maioria da população alemã. A banalidade do mal emergiu do tecido social cotidiano. Arendt (2001) nos fornece como exemplo a história de um médico perseguido por certa muIher decidida a tratar de uma veia varicosa. Tentaram convencer a senhora de que o importante, naquele momento, seria fugir, porque os russos estavam prestes a invadir a região. Todavia, a enferma respondeu sem se alterar: "Nunca vão nos pegar. 0 Führer nunca vai permitir. Antes disso nos põem na câmara de gás" (ARENDT, 2001, p.127). 0 médico olhou em volta, porém ninguém parecia achar a declaração anormal. Esse aspecto banal, indiferente, transforma o gozo em horror. Lacan (1963/ 1998) apontou o problema ao imaginar a vítima de algum carrasco criado por Sade reagindo assim à tortura: observa sua perna e diz, calma mente, "Tu a quebraste". Tal miséria assusta mais do que o próprio ato sádico.

0 mal tem faces diversas. Sade representa um modelo. Como seu oponente era Deus, buscava criminosos atrozes o suficiente para acertar o alvo: seres com apetites incomensuráveis e repugnantes. Entretanto, nem sempre o mal se realiza mediante a grandeza simbolizada por esses personagens. Afinal, mesmo o diabo em pessoa pode ser decepcionante. Os demônios de Goethe e Dostoievski, por exemplo, exalam miséria. Ambos se oferecem como servos de impulsos mais 
mesquinhos do que terríveis. Mefistófeles sequer entra no escritório de Fausto sem cumprir determinadas exigências, tamanha a sua submissão à regra. Cada pal avra e gesto seu circunscreve a impotência. 0 pobre-diabo de Goethe não está entre os grandes. 0 anjo decaído de Ivan Karamazov, por sua vez, encarna 0 fracasso: um serviçal, um palhaço. Tais Príncipes das Trevas, movidos por anseios reles, indicam apenas a soma das fraquezas humanas (NEIMAN, 2003).

A banalidade do demônio provoca desconforto. Sade conquistou nossa imaginação porque almejamos tanto os heróis quanto o tipo certo de vilão. Goethe e Dostoievski, todavia, resistiram à tentação de descrever o mal atribuindo-Ihe "grandeza satânica". Eichmann espanta, pois se esperava encontrar uma personagem sádica, mas se vê um idiota. Horrível é saber que alguém tão desprovido de ferocidade infernal participou da produção em massa de cadáveres - participou da produção de tamanho mal.

\section{O ESTRANGEIRO}

Em 1938, Freud escrevia um texto sobre a origem do judaísmo e as características do "povo eleito". No preâmbulo da segunda parte de Moisés e o monotésmo (1939/ 1996, p.71) lemos: "Estamos vivendo num período especialmente marcante. Descobrimos, para nosso espanto, que o progresso aliou-se à barbárie." Se um judeu, vivendo em Viena, na época de ascensão do nazismo resolve falar de seu povo, decerto o anti-semitismo aparece como questão premente. No entanto, o problema não foi abordado de acordo com a lógica do Terceiro Reich - ou seja, a partir da noção de raça. Em vez disso, produziu-se uma leitura a respeito da construção do monoteísmo.

A hipótese de Freud (1939/1996) se apóia sobre o mito da horda. Nos tempos primevos existiu um só Senhor Todo-Poderoso morto pelos filhos. A lembrança desse ato se desvaneceu na memória consciente dos sujeitos. Entretanto, deixou traços permanentes. Quando o egípcio Moisés trouxe a idéia de um Deus único, reviveu a marca do momento inicial da cultura, da religião e da moral. Ao reencontrar o Ser ansiado, os fiéis responderam com temor e submissão à vontade Divina. Contudo, a essência da relação com o Pai é a ambivalência. A hostilidade também despertou: repetiu-se o parricídio. Todavia, no judaísmo não havia possibilidade de se voltar o ódio diretamente contra o Eterno. Assim, Moisés, o fundador do monoteísmo, foi a vítima do crime. 0 Líder teve um final violento no levante de seu povo, que então rejeitou a nova religião. Porém, depois, os judeus recuperaram a crença e recalcaram mais uma vez o homicídio. ${ }^{2}$

\footnotetext{
2 Em M oisés eo monotésmo, Freud (1939/ 1996) usa duas palavras diferentes para tratar da falta de registro consciente dos assassinatos do Pai primevo ou de Moisés: Verdrängung e Verleugnung. Alguns autores já se dedicaram a discutir qual dessas operações é a fundamental para a construção da
} 
Quando tratamos da construção do judaísmo, apresenta-se o modelo de embate de forças próprio ao discurso da Psicanálise. Afinal, o monoteísmo indica o campo social no qual esse saber se produziu, marcando a forma como a ética, 0 desejo e a culpa incidem sobre o sujeito. Por isso, Freud sempre retorna às questões despertadas pela religião nos seus textos a respeito da cultura. 0 nazismo, por sua vez, convoca uma lógica até certo ponto diversa - de maneira que 0 Holocausto e a admitida antipatia dos partidários de Hitler pelo cristianismo significaram, além da destruição de homens, o ataque a um princípio. Buscando a realização total do desejo identificado com a vontade do Líder, os arautos do extermínio imaginaram tamponar a lacuna gerada pela renúncia pulsional e pelo recalcamento. Assim, destituíram o Bem encarnado nas doutrinas morais tradicionais - 0 ato recusado em tais doutrinas passa para o primeiro plano na ideologia que legaliza o crime. Podemos recuperar a fórmula de Lacan em Kant com Sade (1963/ 1998): sobrepondo-se dois Imperativos, relativamente opostos, revela-se a verdade de ambos. Em qualquer caso, o Mal e o Bem coabitam.

Em M oisés e o monotésmo (FREUD, 1939/ 1996), procura-se justamente a verdade esquecida do judaísmo. 0 início daquele artigo dedica-se a provar uma hipótese oculta na história oficial da religião: o fundador do monoteísmo era um egípcio, um estrangeiro. No mínimo, é interessante retomar essa idéia considerando a descrição feita por Arendt (2001) da posição dos judeus na Europa.

Freud (1939/ 1996, p.127) estava bastante consciente do traço distintivo que envolvia essa posição: "Os judeus têm uma opinião particularmente elevada de si mesmos [...], são inspirados por uma confiança singular na vida, como a que deriva da posse secreta de algum bem precioso - pessoas piedosas chamá-loiam de confiança em Deus." Esse grande amor-próprio não chega a causar espanto. Afinal, trata-se do "povo eleito" pelo Criador, especialmente próximo d'Ele. U ma parte significativa dos habitantes do velho continente "reagiu como se acreditasse em tal superioridade [...]. Quando se é o favorito declarado do pai temido, não se precisa ficar surpreso com o ciúme dos irmãos" (FREUD, 1939/ 1996, p.127). De Caim eAbel até José, as fraternidades do texto sagrado atestam isto.

Moisés, ao criar os judeus, ofertou-Ihes a santidade junto com uma conseqüente marca misteriosa, capaz de mantê-los superiores e separados dos demais homens. Obviamente outros grupos também possuíam uma auto-estima elevada, mas o valor atribuído ao "povo eleito" recebeu um arrimo religioso. "Devido

cultura, da religião e da moralidade (ver, por exemplo, o texto de Lemérer, 1998, sobre o valor essencial da Verleugnung) . Não me deterei em tal ponto. Limito-me a apresentar a questão, preservando a diversidade implícita ao trabal ho de Freud. Podemos dizer que, na criação do corpo social em geral - assim como na da doutrina judaico-cristã especificamente - vemos em ação a Verdrängung, a Verleugnung e a Verwerfung. Portanto, manterei a duplicidade de termos encontrada em Moisés e o monotésmo (FREUD, 1939/ 1996). 
à relação particularmente íntima com seu Deus, adquiriu uma parcela da grandeza dele" (FREUD, 1939/ 1996, p.127). De acordo com Freud, os judeus identificaram-se com o egípcio excepcional que fundou a dignidade da fé monoteísta. Desse modo, permaneceram, como diz Arendt (2001), estrangeiros enigmáticos em todos os lugares.

Todavia, Freud (1939/1996) fala ainda de uma segunda verdade, citada antes, recusada pelo judaísmo: 0 assassinato de Moisés. Portanto, a fórmula geral proposta é a seguinte: mata-se o estrangeiro. Na história recalcada da religião surge o preceito promovido pelo nazismo.

Promulgou-se o "não matarás" para impedir o sujeito de realizar um dos seus desejos mais caros - punindo qualquer infração. Assim, a doutrina religiosa pretende impor limites ao Mandamento do gozo. No entanto, a renúncia pulsional nunca pode ser absoluta - é preciso um espaço de expressão. Por isso a fraternidade exige a segregação. Freud (1930/ 1996) chama tal mecanismo de "narcisismo das pequenas diferenças": a união de um grupo se solidifica por meio da exacerbação da agressividade para com as pessoas excluídas dessa comunidade, transformadas então na encarnação do mal que deve ser apartado.

A aversão pela diferença traduz uma afirmação narcísica. 0 amor-próprio trabal ha para a preservação do sujeito, como se a diversidade humana implicasse incompatibilidade e concorrência. Ademais, a satisfação obtida através da opressão contra os estrangeiros compensa a muitos pelas injustiças sofridas entre os seus semelhantes: "um plebeu infeliz [...] não deixava de ser um cidadão romano, com sua quota na tarefa de governar outras nações e ditar suas leis" (FREUD, 1927/ 1996, p.24).

A agressividade se volta preferencialmente para os pormenores de diferenciação. É comum, por exemplo, a rivalidade dos moradores de cidades vizinhas. Nesse sentido "os judeus, espalhados por toda parte, prestavam um útil serviço às civilizações dos que os acolheram" (FREUD, 1930/ 1996, p.136). Afinal, eles se distinguiam de seus países "hospedeiros" de forma pouco óbvia. Como em vários lugares dominados pelo anti-semitismo o "povo eleito" estava entre os grupos mais antigos da população, sua desigualdade era até certo ponto indefinível, vinculada a uma tradição "mãe" do cristianismo hegemônico, porém misteriosa diante do olhar europeu.

Portanto, no Terceiro Reich, a hostilidade se exerceu contra 0 estrangeiro próximo que, por possuir um suposto poder enigmático - capaz de instrumentálo a manipular o destino dos Estados - incorporava tanto a distinção quanto a cobiça. Desse modo, os judeus detinham um posto almejado e, simultaneamente, representavam o elemento inassimilável para o modelo ideal anti-semita. Os partidários de Hitler aspiravam reconstruir a definição humana atirando o inapreensível ao fogo para, então, identificar-se com ele. 
A ideologia descreve a sociedade como um todo harmônico e complementar, no qual cada integrante contribui de acordo com sua função. 0 discurso nazista produziu novos vínculos para sujeitos desenraizados mediante a tentativa de suturar a ruptura irredutível entre a comunidade e o sonhado equilíbrio natural. Todavia, uma pergunta insistia: como lidar com as incessantes lutas antagônicas, fruto da indelével agressividade? Para forjar uma resposta, o judeu assumiu 0 lugar do corpo estranho que instauraria a corrupção no tecido social hipoteticamente sadio. 0 "povo eleito" encarnou a impossibilidade estrutural do grupo, ofertando uma existência palpável e imaginariamente eliminável para o resto engendrado pela cultura. Por isso, demarcou o ponto de irrupção do gozo no Terceiro Reich. Exercitando sua hostilidade contra o estrangeiro íntimo, os carrascos visavam compensar a identificação ideal malograda (ZIZEK, 1992). Ou seja, matando homens pretendeu-se exorcizar as faltas da fraternidade - suas pequenas diferenças - em favor da constituição da perfeição. Contudo, ao afogar a Lei no gozo, Hitler gerou só horror e crimes.

Assim, a ficção ideológica se organiza por meio do combate ao elemento que circunscreve sua impossibilidade. Entretanto, os desvios e as degenerações do funcionamento social são produtos necessários ao sistema. 0 conceito de "narcisismo das pequenas diferenças" evidencia justamente 0 quanto a fraternidade precisa de um termo externo e heterogêneo para se sustentar. Por conseguinte as fal has no projeto igualitário indicam a verdade da cultura: seu caráter antagônico e hostil. Devemos reconhecer nos traços atribuídos aos judeus pelos nazistas o efeito indelével, porém ideologicamente renegado, da vida no grupo.

\section{CONCLUSÃO}

As paixões que devoravam a Europa no fim da década de 1930 mostram o quanto os ideais empuxam ao crime. Cada ideologia constrói o nó do gozo com a Lei de uma maneira particular. Afinal, ainda que a legitimidade do horror não represente um fenômeno global, a ambivalência dos Imperativos é partilhada pela humanidade. M oisés e o monotésmo (FREUD, 1939/ 1996) foi escrito sob o impacto do anti-semitismo. Todavia, o texto não vincula o "mata-se o estrangeiro" apenas aos nazistas; faz a fórmula intervir na própria tradição judaica.

Freud revela como, "em nome do que há de melhor em nós, em nome dos sacrifícios para os quais estamos prontos, por amor à instância paterna, podemos nos transformar em criminosos" (MELMAN, 1999, p.23). Antes das declarações de Eichmann, em seu julgamento, provocarem assombro, a psicanálise já indicava que mesmo os traços mais nobres são passíveis de converter sujeitos comuns em facínoras. Se a idéia da universalização do horror serviu - equivocadamente - para eclipsar responsabilidades, a atribuição do mal a um restrito e exclusivo conjunto de monstros desumanos também foi útil para minimizar 
nossa culpa, contudo jamais para trabal harmos com a verdade. Como comenta Zizek (1992), a atração de Freud (1914/ 1996) pelo Moisés de Michelangelo está em vislumbrar a imagem de um homem prestes a ceder à fúria destrutiva, mas com força para se dominar e não quebrar as Tábuas da Lei. Embora ninguém se isente do desejo celerado, qualquer um tem a chance de abdicar de sua consumação em ato.

Recebido em 3/ 4/ 2005. Aprovado em 28/ 9/ 2005.

\section{REFERÊNCIAS}

ARENDT, H. (2000). Origens do totalitarismo. São Paulo: Companhia das Letras.

. (2001) Eichmann em Jerusalém: Um relato sobre a banalidade do mal. São Paulo: Companhia das Letras.

FREUD, S. (1996) Edição standard brasileira das obras completas deSigmund Freud. Rio de Janeiro: Imago.

(1913) "Totem e tabu", v.XIII, p.13-163.

(1914) “O Moisés de Michelangelo", v.XIII, p.213-241.

(1921) "A psicologia de grupo e a análise do ego", v.XVIII, p.89-179.

(1927) "O futuro de uma ilusão", v.XXI, p.13-71.

(1930) "Mal-estar na civilização", v.XXI, p.75-171.

(1939) "Moisés e o monoteísmo", v.XXIII, p.13-161.

LACAN, J. (1950/ 2003). "Premissas a todo desenvolvimento possível da criminologia" in: Outros Escritos, Rio de Janeiro: Jorge Zahar. (1956/ 1998) "Seminário sobre 'A carta roubada'", in Escritos,

Rio de Janeiro: Jorge Zahar. Zahar.

LEMÉRER, B. (1998) Les deux M oïse de Freud, Toulouse: Érès.

MELMAN, C. (1999) "La croyance", in Bulletin de la Association freudienne internationale, n. 84, Paris: Climats, p. 16-23.

MELVILLE, H. (1986) Bartleby, o escriturário, Rio de Janeiro: Rocco.

NEIMAN, S. (2003) 0 mal no pensamento moderno: Uma história alternativa da filosofia, Rio de Janeiro: Difel.

ZIZEK, S. (1992) Eles não sabem o que fazem, Rio de Janeiro: Jorge Zahar.

Verônica Martinelli

veronicam@infolink.com.br 